doi: $10.31140 /$ j.vestnikib.2017.2(200).2

\title{
АГАРИКОИДНЫЕ БАЗИДИОМИЦЕТЫ ЗАКАЗНИКА «ДОН-ТЫ» (РЕСПУБЛИКА КОМИ)
}

\author{
М.А. Паламарчук \\ Федеральное государственное бюджетное учреждение науки \\ Институт биологии Коми научного центра Уральского отделения РАН, Сыктывкар \\ E-mail: palamarchuk@ib.komisc.ru
}

\begin{abstract}
Аннотация. Впервые приведены сведения о разнообразии агарикоидных базидиомицетов заказника «Дон-ты» (Усть-Куломский район, Республика Коми). Рассмотрены особенности таксономической и трофрической структуры микобиоты. Представлен аннотированный список из 103 видов и внутривидовых таксонов агарикоидных базидиомицетов, выявленных в районе исследования. Впервые для Республики Коми отмечено пять видов: Lepiota cortinarius J. E. Lange, Cortinarius bivelus (Fr.) Fr., Cortinarius latus (Pers.) Fr., Pholiota astragalina (Fr.) Singer, Panus conchatus (Bull.) Fr.
\end{abstract}

Ключевые слова: агарикоидные базидиомицеты, микобиота, заказник «Дон-ты», Республика Коми

\section{Введение}

Первые сведения об агарикоидных базидиомицетах Республики Коми были получены специалистами Ботанического института АН СССР, которые проводили стационарные исследования растительности лесотундры на северо-востоке Республики Коми (в районе ст. Сивой Маски) в начале 1960-х гг. Результатом этих исследований стала работа Б.П. Василькова, в которой дан список 62 видов (Васильгов, 1970). В 1990 г. вышла гпига Н.С. Котелиной «Грибы тайги и тундры» (1990), в которой рассказывается об основных видах съедобных и ядовитых грибов, растущих в лесах и тундре Республики Коми. Приводятся сведения об их распространении и запасах. Дан указатель русских, коми и латинских названий 114 видов грибов, из которых 98 видов относятся к агарикоидным базидиомицетам. $\kappa$ сожалению, точные районы сборов образцов не указаны. Н.С. Котелиной собрана и первая в Институте биологии Коми НЦ УрО РАН коллекция грибов, однако уцелела только небольшая часть этих сборов.

Планомерное изучение микобиоты агарикоидных базидиомицетов Республики Коми начато в 1999 г. Особое внимание было сосредоточено на инвентаризации макромицетов западного макросклона Урала, где расположены две крупнейшие в России особо охраняемые природные территории - Печоро-Илычский биосферный заповедник (Северный Урал) и национальный парк «Югыд ва» (Приполярный Урал) (Паламарчук, 2012, 2016). В то же время обширная равнинная часть Республики Коми осталась практически не исследованной в отношении выявления разнообразия агарикоидных базидиомицетов. В частности, для Усть-Куломского района, расположенного на юговостоке Республики Коми в бассейне р. Вычегды, сведения об агариковых грибах полностью отсутствовали. В августе 2008 г. впервые проведено исследование микобиоты заказника «Дон-ты», расположенного в центре Усть-Куломского района.

\section{Материалы и методы}

Заказник «Дон-ты» расположен на водоразделе рек Вычегды и Куломъю к юго-востоку от с. Дон в Усть-Куломском районе Республики Коми. В его границах охраняется древесно-кустарничково-сфагновое болото переходного типа, представляющее собой эталон типичного болота подзоны средней тайги европейского северо-востока России. Заказник учрежден в статусе памятника природы в 1978 г., а в 1989 г. переведен в категорию «заказник». Большая часть территории резервата покрыта болотами. По границам болот распрострапспы соспяки сфагшовыс. Примылагощие к озеру песчаные гряды занимают сосняки кустарничково-зеленомошные, реже - сосняки лишайниковые. Отмечены первичные осинники чернично-зеленомошные и еловые кустарничково-зеленомошные леса. На заболоченных берегах оз. Донское распространены ивняки разнотравно-осоковые (Кадастр..., 2014).

Сбор материала проводили августе 2008 г. в окрестностях оз. Донское. В работе использован наиболее распространенный в микологии маршрутный метод. Исследованиями были охвачены все растительные сообщества, представленные на данной территории. Материал гербаризировали по стандартной методике (Бондарцев, 1950; Гербарное дело, 1995). Всего было собрано 130 гербарных образцов. На маршрутах находки обычных и широко распространенных видов, легко определимых в поле, фиксировали в полевом дневнике.

Идентификацию материала осуществляли в отделе флоры и растительности Севера Института биологии Коми НЦ УрО РАН. Микроструктуры изучали на высушенном материале с использованием микроскопа «Микмед 2》 и стандартного набора реактивов (КОН $5 \%$, реактив Мельцера для определения амилоидной и декстриноидной реакции). Изученные образцы хранятся в гербарии Института биологии Коми НЦ УрО РАН (SYKO).

\section{Результаты и их обсуждение}

На территории заказника «Дон-ты» выявлено 103 вида агарикоидных базидиомицетов, относящихся к 43 родам, 22 семействам и пяти порядкам. Все виды приведены впервые для района ис- 
следования, а пять видов - для Республики Коми.

Ведущими семействами являются Cortinariaceae, Strophariaceae, Tricholomataceae, Boletaceae, Russulaceae (табл. 1), что характерно для микобиот лесной зоны Голарктики. Остальные семейства содержат менее пяти видов. Обилие видов в родах Cortinarius, Lactarius, Mycena, Galerina, представители которых широко распространены в таежной зоне, указывает на бореальный характер изученной микобиоты (табл. 2).

Субстрат - важнейший фактор в жизни шляпочных грибов, поскольку, являясь гетеротрофными организмами, они получают из него все необходимые питательные вещества. По типу питания выявленные агарикоидные базидиомицеты разделены на сапротрофы, симбиотрофы и паразиты. Сапротрофы, в свою очередь, по питающему субстрату разбиты на семь групп (сапротрофы на опаде, подстилке, гумусе, древесине (ксилотрофы), плодовых телах макромицетов (микотрофы), мхах (бриотрофы), углях (карботрофы) (Столярская, 1996).

Микоризообразователи лидируют почти во всех голарктических микобиотах, но особенно велика их роль в бореальных лесах умеренной зоны и горных лесах, которые сложены преимущественно древесными растениями, образующими эктотрофную микоризу. В анализируемой микобиоте на их долю приходится 55 видов (51\% от общего числа видов). Это в основном представители семейств Cortinariaceae (21 вид), Russulaceae и Boletaceae (по восемь видов).

Широта специализации у разных видов симбиотрофных грибов различная. Для изученной территории отмечено, что $36 \%$ микоризообразователей вступают в симбиоз с хвойными деревьями, $31 \%$ - с лиственными и $33 \%$ макромицетов не специализированы в отношении древесной породы. Только 28 видов (51\% от общего числа микоризообразователей) являются облигатными симбиотрофами, остальные таксоны способны образовывать микоризу с несколькими видами древесных растений. Среди хвойных больше всего облигатных микоризообразователей отмечено у сосны (10 видов). Это связано с преобладанием на исследуемой территории сосновых лесов и лесов с участием Pinus silvestris. Среди них такие виды, как Cortinarius latus, C.mucosus, Tricholoma equestre, Boletus pinophilus, Gomphidius roseus, Suillus bovinus и др. Ельники на территории заказника занимают небольшие площади, что отражается и на количестве симбиотрофов с Picea obovata, их выявлено только пять видов (Cortinarius brunneus, C. collinitus, C. sanguineus, Boletus edulis, Gomphidius glutinosus). Cpe-
Ведущие по числу видов

Таблица 1

оидных базидиомицетов заказника «Дон-ты»

мейства агарикой

\begin{tabular}{|c|c|c|c|c|}
\hline \multirow[b]{2}{*}{ Семейство } & \multicolumn{2}{|c|}{ Число видов } & \multirow{2}{*}{\begin{tabular}{|c} 
Место \\
в микобиоте \\
по числу \\
видов
\end{tabular}} & \multirow[b]{2}{*}{$\begin{array}{l}\text { Число } \\
\text { родов }\end{array}$} \\
\hline & Абсолютное & \begin{tabular}{|c|} 
Доля от \\
общего числа \\
видов, \%
\end{tabular} & & \\
\hline Jortinariaceae & 21 & 20.2 & 1 & 1 \\
\hline Strophariaceae & 14 & 13.5 & 2 & 5 \\
\hline Tricholomataceae & 9 & 8.7 & 3 & 5 \\
\hline Boletaceae & 8 & 7.7 & $4-5$ & 4 \\
\hline Russulaceae & 8 & 7.7 & $4-5$ & 2 \\
\hline Agaricaceae & 6 & 5.8 & $6-7$ & 4 \\
\hline Mycenaceae & 6 & 5.8 & $6-7$ & 1 \\
\hline Marasmiaceae & 5 & 4.8 & 8 & 2 \\
\hline
\end{tabular}

ди лиственных пород больше всего микоризообразователей обнаружено у березы (11 видов). Наиболее обычны в заказнике следующие таксоны: Leccinum scabrum, L. versipelle, Cortinarius armillatus, C. pholideus, Russula aeruginea и др. Два вида (Leccinum aurantiacum, Cortinarius decoloratus) являются облигатными симбиотрофами осины. Из видов, не имеющих строгой приуроченности к какой-либо древесной породе, здесь встречаются Amanila muscaria, Corlinarius caperatus, C. cinnamomeus, Laccaria laccata, Paxillus involutus, Inocybe lacera, Lactarius rufus и др.

На долю сапротрофов в анализируемой биоте приходится 49\%. Среди них преобладают ксилотрофы и подстилочные сапротрофы (по 17 видов). Большинство ксилотрофов относится к семейству Strophariaceae (семь видов). Довольно часто встречаются Pluteus cervinus, Mycena laevigata, Gymnopilus penetrans, G. picreus и Pleurotus pulmonarius. Среди подстилочных сапротрофов в лесах заказника обычны такие виды, как Cystoderma amianthinum, Entoloma cetratum, Ampulloclitocybe clavipes, Gymnopus dryophilus, Mycena metata, Cantharellula umbonata и др. Группа бриотрофов представлена шестью видами. Самые обычные из них Hypholoma elongatum, Tephrocybe palustris и Galerina paludosa, доминирующие на болотах заказника. На исследуемой территории выявлено пять видов гумусовых сапротрофов: Agaricus semotus, Lepiota clypeolaria, L. cortinarius, L. magnispora, Lyophyllum decastes. Сапротрофы на опаде представлены четырьмя таксонами. Наиболее часто

Таблица 2

Ведущие по числу видов роды агарикоидных базидиом ицетов заказника «Дон-ты»

\begin{tabular}{l|c|c|c}
\hline \multirow{2}{*}{ Род } & \multicolumn{2}{|c|}{ Число видов } & \multirow{2}{*}{$\begin{array}{c}\text { Место } \\
\text { в микобиоте }\end{array}$} \\
\cline { 2 - 3 } & Абсолютное & $\begin{array}{r}\text { Доля от общего } \\
\text { числа видов, \% }\end{array}$ & по числу видов \\
\hline Cortinarius & 21 & 20.2 & 1 \\
Lactarius & 6 & 5.8 & $2-3$ \\
Mycena & 6 & 5.8 & $2-3$ \\
Pholiota & 5 & 4.8 & 4 \\
Galerina & 4 & 3.8 & 5
\end{tabular}


встречаются широко распространенные виды Gymnopus androsaceus и G. perforans. На старых сгнивших плодовых телах представителей семейства Russulaceae обнаружено два вида микотрофа (Collybia cirrhata и C. tuberosa). Один вид (Pholiota highlandensis) является карботрофом. Он был собран на старом кострище, на лесной дороге. Опенок осенний - Armillaria mellea - является факультативным паразитом. Все находки этого вида в заказнике были отмечены на поврежденных деревьях или валеже.

На территории заказника «Дон-ты» наиболее подробно были исследованы следующие местообитания: сосняки, мелколиственные, смешанные леса и болота. Наибольшего видового разнообразия агарикоидные базидиомицеты достигают в сосновых лесах (42 вида). Довольно обычны здесь следующие виды: Cystoderma amianthinum, Cortinarius caperatus, C. croceus, C. mucosus, C. semisanguineus, Laccaria laccata, Russula decolorans и др. Среди видов, новых для республики, в сосняках были обнаружены Cortinarius bivelus и C. latus. Для смешанных лесов отмечено 37 таксонов, это такие виды, как Cortinarius armillatus, C. caninus, C. pholideus, Ampulloclitocybe clavipes, Inocybe lacera, Mycena laevigata, Hebeloma mesophaeum, Russula aeruginea и др. В данном местообитании были встречены новые для республики виды: Lepiota cortinarius и Panus conchatus. В мелколиственных лесах отмечено только 10 видов (Cortinarius balaustinus, Entoloma minutum, Lactarius vietus, Lepiota ventriosospora и др.), что связано с их недостаточной изученностью. Интересна находка довольно редкого вида - Pholiota astragalina. На болотах было собрано лишь 12 видов, данные местообитания характеризует бедное видовое разнообразие агарикоидных базидиомицетов. Типичными обитателями болот являются Hypholoma elongatum, Tephrocybe palustris, Cortinarius tubarius, Galerina paludosa и др.

Из видов, занесенных в Красную книгу Республики Коми (2009), на территории заказника «Дон-ты» был встречен Tricholomopsis decora. $\mathrm{OH}$ растет в сосновых лесах на валеже. Интересны находки редкого для России вида Lepiota cortinarius. В России она известна из Иркутской области (Астапенко, 1990) и со Среднего Урала (Висимский заповедник) (Марина, 2006). Общее распространение: Европа, Азия, Северная Америка. Растет в лиственных и смешанных лесах, везде редка. Вид включен в Красные книги Норвегии (The 2010 Norwegian..., 2010) и Финляндии (The 2010 Red..., 2010).

Ниже приведен список видов агарикоидных базидиомицетов, выявленных для территории заказника «Дон-ты». Таксоны расположены в нем по системе, принятой в 10-м издании «Словаря грибов Айнсворта и Бисби" (Ainsworth..., 2008). Номенклатура, если она не противоречит 10-му изданию словаря грибов, и сокращения авторов таксонов грибов приведены в соответствии с рекомендациями международного таксономического ресурса Index Fungorum (2016).

Для каждого вида указаны местонахождение, местообитание, субстрат, дата сбора, номер в гербарии Института биологии Коми НЦ (SYKOf). Для обычных и широко распространенных видов, легко определимых в поле, сведения об отдельных находках не детализированы. Для некоторых видов приведены синонимы. Знаком (*) отмечены виды, новые для Республики Коми.

Основные точки, в окрестностях которых проводили коллекционные сборы: дорога на Кадомские озера, водораздел озер Донское и Большое Кадомское - $61^{\circ} 34^{\prime} 38.0^{\prime \prime}$ с.ш., $53^{\circ} 59^{\prime} 53.9^{\prime \prime}$ в.д., 126 м над ур.м.; окрестности оз. Донское, 10 км на восток от с. Дон $-61^{\circ} 36^{\prime} 06.7^{\prime \prime}$ с.ш., 54 04'38.5" в.д., 91 м над ур.м.; окрестности оз. Донское, 9 км на восток от с. Дон $-61^{\circ} 36^{\prime} 26.7^{\prime \prime}$ с.ш., 54 $03^{\prime} 10.5^{\prime \prime}$ в.д., 110 м над ур.м.; окрестности оз. Донское, база Северная, $8.5 \mathrm{kм} \mathrm{на} \mathrm{восток} \mathrm{от}$ с. Дон $-61^{\circ} 37^{\prime} 05.9^{\prime \prime}$ с.ш., 54 03'14.6" в.д., $115 \mathrm{м}$ над ур.м.; 8 км на северо-восток от с. Дон $61^{\circ} 38^{\prime} 34.6^{\prime \prime}$ с.ш., $54^{\circ} 03^{\prime} 27.7^{\prime \prime}$ в.д., 112 м над ур.м.

\section{Порядок AGARICALES}

Семейство Agaricaceae

Agaricus semotus Fr. - дорога на Кадомские озера, водораздел озер Донское и Большое Кадомское, сосняк чернично-зеленомошный, на почве, 28.08.2008 (SYKOf 604).

Cystoderma amianthinum (Scop.) Fayod -8 км на юго-восток от с. Дон, сосняк зеленомошный, на опаде, 26.08.2008 (SYKOf 627).

Cystodermella cinnabarina (Alb. et Schwein.) Harmaja - 8 км на юго-восток от с. Дон, сосняк зеленомошный, на подстилке, 26.08.2008 (SYKOf $628)$.

Lepiota clypeolaria (Bull.) P. Kumm. - окрестности оз. Донское, база Северная, 8.5 км на восток от с. Дон, смешанный лес, на почве, 27.08 . 2008 (SYKOf 630).

*L. cortinarius J.E. Lange - дорога на Кадомские озера, смешанный елово-осиновый лес, на почве, 28.08.2008 (SYKOf 831).

L. magnispora Murrill (= L. ventriosospora D.A. Reid) - дорога на Кадомские озера, водораздел озер Донское и Большое Кадомское, осинник, на почве, 28.08.2008 (SYKOf 629).

\section{Семейство Amanitaceae}

Amanita fulva Fr. - окрестности оз. Донское, база Северная, 8.5 км на восток от с. Дон, смешанный лес, на почве, 27.08.2008 (SYKOf 624).

A. muscaria (L.) Lam. - окрестности оз. Донское, смешанные и сосновые леса, на потве.

A. porphyria Alb. et Schwein. - 10 км на восток от с. Дон, сосняк зеленомошный, на почве, 27.08. 2008 (SYKOf 625). 
Семейство Cortinariaceae

Cortinarius armeniacus (Schaeff.) Fr. -10 км на восток от с. Дон, сосняк зеленомошный, на почве, 27.08.2008 (SYKOf 636).

C. armillatus (Fr.) Fr. - окрестности оз. Донское, смешанный лес, на почве, 27.08.2008 (SYKOf 579).

C. balaustinus Fr. - дорога на Кадомские озера, водораздел озер Донское и Большое Кадомское, осинник, на почве, 28.08.2008 (SYKOf 635).

C. biformis Fr. -9 км на восток от с. Дон, сосняк зеленомошный, на почве, 27.08.2008 (SYKOf 646).

${ }^{*}$ C. bivelus (Fr.) Fr. -10 км на восток от с. Дон, сосняк зеленомошный, на почве, 27.08.2008 (SYKOf 639).

C. bolaris (Pers.) Fr. - дорога на Кадомские озера, сосняк тернично-зеленомошный, на потве, 28.08.2008 (SYKOf 576).

C. caninus (Fr.) Fr. - окрестности оз. Донское, база Северная, 8.5 км на восток от с. Дон, смешанный лес, на почве, 27.08.2008 (SYKOf 641).

C. caperatus (Pers.) Fr. (= Rozites caperata (Pers.: Fr.) P. Karst.) - окрестности оз. Донское, сосняк зеленомошный, на почве, 27.08.2008 (SYKOf 574).

C. cinnamomeus (L.) Fr. - дорога на Кадомские озера, водораздел озер Донское и Большое Кадомское, сосняк зеленомошный, на почве, 28.08.2008 (SYKOf 634).

C. collinitus (Sowerby) Fr. -8 км на юго-восток от с. Дон, сосняк зеленомошный, на почве, 26.08. 2008 (SYKOf 631).

C. croceus (Schaeff.) Gray - 8 км на юго-восток от с. Дон, сосняк зеленомошный, на почве, 26.08. 2008 (SYKOf 633); дорога на Кадомские озера, водораздел озер Донское и Большое Кадомское, сосняк зеленомошный, на почве, 28.08.2008 (SYKOf 637).

C. hemitrichus (Pers.) Fr. -8 км на юго-восток от с. Дон, сосняк зеленомошный с березой, на почве, 26.08.2008 (SYKOf 644).

*C. latus (Pers.) Fr. - дорога на Кадомские озера, водораздел озер Донское и Большое Кадомское, сосняк зеленомошный, на почве, 28.08.2008 (SYKOf 642).

C. mucosus (Bull.) J. Kickx - окрестности оз. Донское, сосняк зеленомошный, на почве, 27.08. 2008 (SYKOf 577).

C. purpureus (Bull.) Bidaud, Moënne-Locc. et Reumaux (=C. phoeniceus (Vent.) Maire) - дорога на Кадомские озера, водораздел озер Донское и Большое Кадомское, сосняк бруснично-зеленомошный, на почве, 28.08.2008 (SYKOf 640).

C. pholideus (Lilj.) Fr. -8 км на юго-восток от c. Дон, сосняк зеленомошный с березой, на почве, 26.08.2008 (SYKOf 671); окрестности оз. Донское, сосняк зеленомошный, на потве, 27.08.2008 (SYKOf 578).
C. sanguineus (Wulfen) Fr. - c. Дон, около лодочной станции, березняк заболоченный, на почве, 27.08.2008 (SYKOf 638).

C. semisanguineus (Fr.) Gillet - окрестности оз. Донское, сосняк зеленомошный, на почве, 27.08. 2008 (SYKOf 580).

C. tabularis (Fr.) Fr. (= C. decoloratus (Fr.) Fr.) 8 км на юго-восток от с. Дон, сосняк зеленомошный с березой, на почве, 26.08.2008 (SYKOf 672).

C. trivialis J.E. Lange -8 км на юго-восток от с. Дон, сосняк зеленомошный с березой, на почве, 26.08.2008 (SYKOf 643).

C. tubarius Ammirati et A.H. Sm. - 9 км на восток от с. Дон, сфагновое болото, на почве, 27.08.2008 (SYKOf 632).

\section{Семейство Entolomataceae}

Entoloma cetratum (Fr.) M.M. Moser -8 км на юго-восток от с. Дон, сосняк зеленомошный с березой, на подстилке, 26.08.2008 (SYKOf 694).

E. minutum (P. Karst.) Noordel. - c. Дон, около лодочной станции, березняк заболоченный, на почве, 27.08.2008 (SYKOf 693).

\section{Семейство Hydnangiaceae}

Laccaria laccata (Scop.) Cooke -8 км на юговосток от с. Дон, сосняк зеленомошный, на почве, 26.08.2008 (SYKOf 606); 9 км на восток от с. Дон, сфагновое болото, на почве, 27.08.2008 (SYKOf 647).

\section{Семейство Hygrophoraceae}

Ampulloclitocybe clavipes (Pers.) Redhead, Lutzoni, Moncalvo et Vilgalys (= Clitocybe clavipes (Pers.) P. Kumm.) - окрестности оз. Донское, база Северная, 8.5 км на восток от с. Дон, смешанный лес, на подстилке, 27.08.2008 (SYKOf 653).

Lichenomphalia umbellifera (L.) Redhead, Lutzoni, Moncalvo et Vilgalys - окрестности оз. Донское, сосняк зеленомошный, на почве.

\section{Семейство Inocybaceae}

Flammulaster carpophilus var. rhombosporus (G.F. Atk.) Vellinga - окрестности оз. Донское, база Северная, 8.5 км на восток от с. Дон, смешанный лес, на опаде, 27.08.2008 (SYKOf 626).

Inocybe lacera (Fr.) P. Kumm. - 8 км на юговосток от с. Дон, сосняк зеленомошный с березой, на почве, 26.08.2008 (SYKOf 670).

Phaeomarasmius erinaceus (Fr.) Scherff. ex Romagn. - c. Дон, около лодочной станции, березняк заболоченный, на ветках ивы, 27.08.2008 (SYKOf 575).

\section{Семейство Lyophyllaceae}

Lyophyllum decastes (Fr.) Singer - дорога на Кадомские озера, водораздел озер Донское и Большое Кадомское, сосняк зеленомошный, на дороге, на почве, 28.08.2008 (SYKOf 677). 
Tephrocybe palustris (Peck) Donk - 9 км на восток от с. Дон, сфагновое болото, среди сфагнума, 27.08.2008 (SYKOf 695).

\section{Семейство Marasmiaceae}

Gymnopus acervatus (Fr.) Murrill - 8 км на юговосток от с. Дон, сосняк зеленомошный с березой, на погруженной в почву древесине, 26.08. 2008 (SYKOf 681).

G. androsaceus (L.) Della Maggiora et Trassinelli (= Marasmius androsaceus (L.) Fr) - окрестности оз. Донское, сосновые и смешанные леса, на хвое.

G. dryophilus (Bull.) Murrill (= Collybia dryophila (Bull.: Fr.) P. Kumm.) - окрестности оз. Донское, сосновые и смешанные леса, на подстилке.

G. perforans (Hoffm.) Antonin et Noordel. $-8 \mathrm{\kappa m}$ на юго-восток от с. Дон, сосняк зеленомошный, на опавшей хвое, 26.08.2008 (SYKOf 829).

Rhodocollybia butyracea f. asema (Fr.) Antonin, Halling et Noordel. - окрестности оз. Донское, база Северная, 8.5 км на восток от с. Дон, смешанный лес, на подстилке, 27.08.2008 (SYKOf 680).

\section{Семейство Mycenaceae}

Mycena clavicularis (Fr.) Gillet - 9 км на восток от с. Дон, сосняк зеленомошный, на хвое и шишках сосны, 27.08.2008 (SYKOf 688).

M. flavoalba (Fr.) Quél. - 8 км на юго-восток от с. Дон, сосняк зеленомошный с березой, 26.08. 2008 (SYKOf 697).

M. galericulata (Scop.) Gray - c. Дон, около лодочной станции, березняк заболоченный, на валеже, 27.08.2008 (SYKOf 696).

M. laevigata (Lasch) Gillet -8 км на юго-восток от с. Дон, сосняк зеленомошный с березой, валеж, поросший мхом, 26.08.2008 (SYKOf 687).

M. metata (Secr. ex Fr.) P. Kumm. - 9 км на восток от с. Дон, сосняк зеленомошный, на подстилке, 27.08.2008 (SYKOf 690, SYKOf 691).

M. stylobates (Pers.) P. Kumm. - окрестности оз. Донское, база Северная, 8.5 км на восток от с. Дон, смешанный лес, на подстилке, 27.08. 2008 (SYKOf 689).

\section{Семейство Physalacriaceae}

Armillaria mellea (Vahl) P. Kumm. - окрестности оз. Донское, база Северная, 8.5 км на восток от с. Дон, смешанный лес, на валеже, 27.08. 2008 (SYKOf 607).

\section{Семейство Pleurotaceae}

Pleurotus pulmonarius (Fr.) Quél. - окрестности оз. Донское, база Северная, 8.5 км на восток от с. Дон, смешанный лес, на валеже, 27.08. 2008 (SYKOf 682).

\section{Семейство Pluteaceae}

Pluteus cervinus (Schaeff.) P. Kumm - окрестности оз. Донское, сосняк зеленомошный, на валеже.
P. leoninus (Schaeff.) P. Kumm. - дорога на Кадомские озера, водораздел озер Донское и Большое Кадомское, смешанный елово-осиновый лес, на валеже березы, 28.08.2008 (SYKOf 651).

\section{Семейство Strophariaceae}

Galerina hypnorum (Schrank) Kühner - 9 км на восток от с. Дон, сосняк зеленомошный, на моховой подушке, 27.08.2008 (SYKOf 657).

G. paludosa (Fr.) Kuhner - окрестности оз. Донское, сосняк заболоченный, среди сфагновых мхов.

G. pumila (Pers.) Singer - 8 км на юго-восток от с. Дон, сосняк зеленомошный с березой, около лесной дороги, на мхах, 26.08.2008 (SYKOf 656).

G. vittiformis (Fr.) Singer - 8 км на юго-восток от с. Дон, сосняк зеленомошный с березой, около лесной дороги, среди мхов, 26.08.2008 (SYKOf $655)$.

Gymnopilus penetrans (Fr.) Murrill - 9 км на восток от с. Дон, сосняк зеленомошный, на гнилой древесине, 27.08.2008 (SYKOf 658).

G. picreus (Pers.) P. Karst. - окрестности оз. Донское, база Северная, $8.5 \mathrm{kм} \mathrm{на} \mathrm{восток} \mathrm{от}$ с. Дон, смешанный лес, на валеже, 27.08.2008 (SYKOf 659).

Hebeloma leucosarx P.D. Orton (= Hebeloma velutipes Bruchet) - 9 км на восток от с. Дон, сосняк зеленомошный, на почве, 27.08.2008 (SYKOf 645).

H. mesophaeum (Pers.) Quél. - 8 км на юговосток от с. Дон, сосняк зеленомошный с березой, на почве, 26.08.2008 (SYKOf 673).

Hypholoma elongatum (Pers.) Ricken - c. Дон, около лодочной станции, березняк заболоченный, среди сфагновых мхов, 27.08.2008 (SYKOf 698, SYKOf 699).

*Pholiota astragalina (Fr.) Singer - дорога на Кадомские озера, осинник, на валеже, погруженHом в мох, 28.08.2008 (SYKOf 828).

P. highlandensis (Peck) Quadr. et Lunghini 4 км от с. Дон, сосняк зеленомошный, на старом кострище, на углях, 28.08.2008 (SYKOf 572).

P. lubrica (Pers.) Singer - окрестности оз. Донское, база Северная, 8.5 км на восток от с. Дон, смешанный лес, на валеже, 27.08.2008 (SYKOf 827).

P. spumosa (Fr.) Singer - 8 км на юго-восток от с. Дон, сосняк зеленомошный с березой, на валеже, группой, 26.08.2008 (SYKOf 700).

P. squarrosoides (Peck) Sacc. - окрестности оз. Донское, база Северная, 8.5 км на восток от с. Дон, смешанный лес, на валеже березы, 27.08. 2008 (SYKOf 692).

\section{Семейство Tricholomataceae}

Cantharellula umbonata (J.F. Gmel.) Singer 8 км на юго-восток от с. Дон, сосняк зеленомошный, на подстилке, 26.08.2008 (SYKOf 608).

Clitocybe agrestis Harmaja - 8 км на юго-восток от с. Дон, сосняк зеленомошный с березой 
около дороги, на подстилке, 26.08.2008 (SYKOf 652).

C. odora (Bull.) P. Kumm. - дорога на Кадомские озера, водораздел озер Донское и Большое Кадомское, осинник, на подстилке, 28.08.2008 (SYKOf 654).

Collybia cirrhata (Schumach.) Quel. - 8 км на юго-восток от с. Дон, сосняк зеленомошный с березой, на гнилых макромицетах, 26.08.2008 (SYKOf 674).

C. tuberosa (Bull.) P. Kumm. - дорога на Kaдомские озера, водораздел озер Донское и Большое Кадомское, сосняк зеленомошный, на гнилом пластинчатом грибе, 28.08.2008 (SYKOf 675).

Tricholoma equestre (L.) P. Kumm. (= Tricholoma flavovirens (Pers.: Fr.) S. Lundell) - дорога на Кадомские озера, водораздел озер Донское и Большое Кадомское, сосняк чернично-зеленомошный, на почве, 29.08.2008 (SYKOf 621).

T. imbricatum (Fr.) P. Kumm. - дорога на Kaдомские озера, сосняк лишайниковый, на почве, 28.08.2008 (SYKOf 830).

T. saponaceum (Fr.) P. Kumm. var. squamosum (Cooke) Rea - дорога на Кадомские озера, водораздел озер Донское и Большое Кадомское, сосняк зеленомошный, на лесной дороге, на почве, группами, 28.08.2008 (SYKOf 683).

Tricholomopsis decora (Fr.) Singer - дорога на Кадомские озера, водораздел озер Донское и Большое Кадомское, сосняк чернично-зеленомошный, на гнилой древесине, 28.08.2008 (SYKOf 605).

\section{Порядок BOLETALES}

Семейство Boletaceae

Boletus pinophilus Pilát et Dermek - окрестности оз. Донское, сосновые леса, на почве.

B. edulis Bull. - окрестности оз. Донское, смешанные леса, на почве.

B. subtomentosus L. (= Xerocomus subtomentosus (L.) Quél.) - 2 км от с. Дон, сосново-березовый лес, на почве, 26.08.2008 (SYKOf 581).

Chalciporus piperatus (Bull.) Bataille - окрестности оз. Донское, сосняк зеленомошный, на почве.

Leccinum aurantiacum (Bull.) Gray - окрестности оз. Донское, осинник, на почве.

L. scabrum (Bull.) Gray - 10 км на восток от c. Дон, сосняк чернично-зеленомошный, на почве, 27.08.2008 (SYKOf 648).

L. versipelle (Fr. et Hök) Snell - окрестности оз. Донское, смешанный лес, на почве.

Tylopilus felleus (Bull.) P. Karst - окрестности оз. Донское, сосняк зеленомошный, на почве, 27.08.2008 (SYKOf 582).

\section{Семейство Gomphidiaceae}

Chroogomphus rutilus (Schaeff.) O.K. Mill. 8 км на юго-восток от с. Дон, сосняк зеленомошный, около лесной дороги, на почве, 26.08.2008 (SYKOf 602).
Gomphidius glutinosus (Schaeff.) Fr. - 8 км на юго-восток от с. Дон, сосняк зеленомошный, около лесной дороги, на почве, 26.08.2008 (SYKOf 601).

G. roseus (Fr.) Fr. - 8 км на юго-восток от с. Дон, сосняк зеленомошный, около лесной дороги, на почве, 26.08.2008 (SYKOf 603).

\section{Семейство Paxillaceae}

Paxillus involutus (Batsch) Fr. - окрестности оз. Донское, сосняк зеленомошный, на почве, 27.08.2008 (SYKOf 573).

\section{Семейство Suillaceae}

Suillus bovinus (L.) Roussel - 8 км на юго-восток от с. Дон, сосняк зеленомошный с березой, на почве, 26.08.2008 (SYKOf 650).

S. luteus (L.) Roussel - окрестности оз. Донское, сосновые леса, на почве.

S. variegatus (Sw.) Richon et Roze - окрестности оз. Донское, база Северная, 8.5 км на восток от с. Дон, смешанный лес, на почве, 27.08.2008 (SYKOf 649).

\section{Порядок HYMENOCHAETALES}

Семейство Rickenellaceae

Rickenella fibula (Bull.) Raithelh. - 8 км на юговосток от с. Дон, сосняк зеленомошный с березой, среди мхов, 26.08.2008 (SYKOf 623).

\section{Порядок POLYPORALES}

\section{Семейство Polyporaceae}

*Panus conchatus (Bull.) Fr. (= Lentinus conchatus (Bull.: Fr.) J. Schrot.) - окрестности оз. Донское, база Северная, 8.5 км на восток от с. Дон, смешанный лес, на пне, 27.08.2008 (SYKOf 826).

\section{Порядок RUSSULALES}

Семейство Russulaceae

Lactarius helvus (Fr.) Fr. - дорога на Кадомские озера, водораздел озер Донское и Большое Кадомское, сосняк зеленомошный, на почве, 28.08.2008 (SYKOf 679).

L. mammosus Fr. - дорога на Кадомские озера, водораздел озер Донское и Большое Кадомское, сосняк зеленомошный, на лесной дороге, группами, на почве, 28.08.2008 (SYKOf 686).

L. pubescens Fr. -8 км на юго-восток от с. Дон, сосняк зеленомошный с березой, на почве, 26.08 . 2008 (SYKOf 684).

L. rufus (Scop.) Fr. - окрестности оз. Донское, сосновые и смешанные леса, на почве.

L. torminosus (Schaeff.) Gray - окрестности оз. Донское, смешанный лес, на почве.

L. vietus (Fr.) Fr. - c. Дон, около лодочной станции, березняк заболоченный, на почве, 27.08. 2008 (SYKOf 685).

Russula aeruginea Lindblad ex Fr. - окрестности оз. Донское, база Северная, 8.5 км на восток 
от с. Дон, смешанный лес, на почве, 27.08.2008 (SYKOf 676).

R. decolorans (Fr.) Fr. - 9 км на восток от с. Дон, сосняк зеленомошный, на почве, 27.08. 2008 (SYKOf 678).

\section{Заключение}

Таким образом, на территории заказника «Донты” выявлено 103 вида агарикоидных базидиомицетов, относящихся к 43 родам, 22 семействам и пяти порядкам. Все виды приводятся впервые для района исследования, а пять видов - для Республики Коми. Ведущими семействами являются Cortinariaceae, Strophariaceae, Tricholomataceae, Boletaceae, Russulaceae, что характерно для всей лесной зоны Голарктики. Анализ трофических групп агарикоидных базидиомицетов выявил, что в исследуемой микобиоте наибольшее количество видов относится к микоризообразователям (51\% от их общего числа). На долю сапротрофов приходится $49 \%$, среди них преобладают ксилотрофы и подстилочные сапротрофы. Из видов, занесенных в Красную книгу Республики Коми (2009), был встречен Tricholomopsis decora. Интересна находка редкого для России вида Lepiota cortinarius.

\section{ЛИТЕРАТУРА}

Астапенко, В. В. Дополнение к флоре макромицетов Среднего Приангарья / В. В. Астапенко, Н. П. Кутафьева // Новости систематики низших растений. 1990. - T. 27. - С. 48-52.

Бондарцев, А. С. Руководство по сбору высших базидиальных грибов для научного их изучения / А. С. Бондарцев, Р. А. Зингер // Труды Ботанического института им. В. Л. Комарова АН СССР. - 1950. - Сер. 2 , вып. 6. - С. 499-572.
Васильков, Б. П. Грибы (макромицеты) // Экология и биология растений восточно-европейской тундры / Б. П. Васильков. - Ленинград : Наука, 1970. C. $55-60$.

Гербарное дело : справочное руководство / под ред. Д. В. Гельтмана. - Кью : Королевский ботанический сад, 1995. - 341 с.

Кадастр особо охраняемых природных территорий Республики Коми / под ред. С. В. Дёгтевой, В. И. Пономарева. - Сыктывкар, 2014. - 428 с.

Котелина, Н. С. Грибы тайги и тундры / Н. С. Котелина. - Сыктывкар, 1990. - 128 с.

Красная книга Республики Коми / отв. ред. А. И. Таскаев. - Сыктывкар, 2009. - 791 с.

Марина, Л. В. Агарикоидные базидиомицеты Висимского заповедника (Средний Урал) / Л. В. Марина. - Санкт-Петербург, 2006. - 102 с.

Паламарчук, М. А. Агарикоидные базидиомицеты Печоро-Илычского заповедника (Северный Урал) / М. А. Паламарчук. - Сыктывкар, 2012. - 152 с.

Паламарчук, М. А. Агарикоидные базидиомицеты северной части национального парка «Югыд ва» / М. А. Паламарчук // Микология и фитопатология. - 2016. T. 50, № $1 .-$ C. $24-34$.

Столярская, М. В. Макромицеты (преимущественно агарикоидные базидиомицеты). Аннотированные списки видов / М. В. Столярская, А. Е. Коваленко // Грибы Нижнесвирского заповедника. - Санкт-Петербург : Копи-Сервис, 1996. - Вып. 1. - 59 с.

Ainsworth and Bisby's Dictionary of the Fungi : 10th edn. / P. M. Kirk, P. F. Cannon, D. W. Minter, J. A. Stalpers. - Wallingford : CAB International, 2008. $771 \mathrm{p}$.

Index Fungorum [Электронный ресурс]. - Режим доступа: http://www.indexfungorum.org/Names/ Names.asp.

The 2010 Norwegian Red List for Species / eds. J. A. Kalas, A. Viken, S. Henriksen, S. Skjelseth. - Trondheim : Norwegian Biodiversity Information Centre, 2010. $480 \mathrm{p}$.

The 2010 Red List of Finnish Species / eds. P. Rassi, E. Hyvarinen, A. Justlen, I. Mannerkoski. - Helsinki : Ymparistoministerio and Suomen ymparistokeskus, 2010. - 685 p.

\title{
AGARICOID BASIDIOMYCETES OF «DON-TY» RESERVE (KOMI REPUBLIC)
}

\author{
M. A. Palamarchuk \\ Institute of Biology of Komi Scientific Centre of the Ural Branch of the Russian Academy of Sciences, Syktyvkar
}

Summary. Diversity of agaricoid basidiomycetes of the plain part of the Komi Republic is unexplored by the moment. In August 2008, we for the first time researched mycobiota of the "Don-ty» reserve that located in the central part of the Ust-Kulomskiy District. Material was collected in the vicinities of the lake Donskoye. As a result of the study 103 species of agaricoid basidiomycetes from 43 genera, 22 families and 5 orders were revealed in the "Don-ty» reserve. All the species were noted for the first time in the area under study, 5 species - for the first time for the Komi Republic (Lepiota cortinarius J. E. Lange, Cortinarius bivelus (Fr.) Fr., Cortinarius latus (Pers.) Fr., Pholiota astragalina (Fr.) Singer, Panus conchatus (Bull.) Fr.). The leading families are Cortinariaceae, Strophariaceae, Tricholomataceae, Boletaceae, Russulaceae, the leading genera Cortinarius, Lactarius, Mycena, Galerina that is typical for taiga mycobiota. Species from the Red Book of the Komi Republic are presented in the reserve by Tricholomopsis decora (Fr. Singer).

Mycorrhizal fungi $(51 \%)$ are prevalent in the trophic structure of the reserve mycobiota. Saprotrophic fungi account for $49 \%$ of the biota under study. Among them, saprotrophic on wood and on litter (16\% for each) fungi dominate. Other groups (saprotrophic on humus, on bryophytes, on leaf, on macromycetes, on burnt wood and parasites) are presented by small number of species. The largest species diversity of the agaricoid basidiomycetes was found in pine forests of the reserve (42 species). In mixed forests, 37 species were noted and 10 species - in parvifoliate forests. 12 species were collected from mires.

Key words: agaricoid basidiomycetes, mycobiota, «Don-ty» reserve, Komi Republic 